\title{
The concept of lita'arofu as a multicultural education model to response religious hate speech
}

\author{
Saibatul Hamdi ${ }^{1}$, Khabib Musthofa ${ }^{2}$ \\ Pascasarjana IAIN Palangka Raya ${ }^{1,2}$, Indonesia \\ saibatu198.se@gmail.com¹, khabibmusthofa1996@gmail.com² \\ DOI: 10.18326/attarbiyah.v5i2.91-104
}
Submitted:
Accepted:
Published:
23 October 2020
3 January 2021
6 January 2021

\begin{abstract}
The presence of the Religious Hate Speech (RHS) has had negative impacts such as intolerance, extremism, and even radicalism. Given the increasing number of young people, especially students who may be exposed, it is important that prevention efforts are carried out. One of them is through multicultural education. This study aimed to examine the facts of RHS and offer solutions through the concept of lita'arofu (to recognize each other) as a model of multicultural education. The method used is a literature study (library research by conducting a review of relevant literature and previous research. The results of this study indicate that: (1) the phenomenon of RHS in Indonesia is getting worse, as evidenced by cases of hate speech that actually bring down fellow Muslims; (2) multicultural education is urgent to be implemented in schools to create a moderate understanding of religion; (3) development of the interpretation of lita'arofu in QS. AlHujurat: 13, among others, changing direction from qabilah to ummah, giving choices instead of imposing, and broadening the perspective The lita'arofu model is important to apply, because this model will present a moderate religious narrative to prevent the RHS from spreading.
\end{abstract}

Keywords: multiculturalism, education, religious hate speech 


\section{INTRODUCTION}

The expression of the Religious Hate Speech as expressed by Umar (2019) in his book "Jihad Against Religious Hate Speech (RHS)" seems to confirm that this chaotic problem is increasingly worrying. The group that spreads RHS often threw provocations to other groups who disagreed. For example, the disbelief of the Shi'ah group, heresy against a number of NU religious traditions, and various other misconceptions. Hate speech in the name of religion as the main problem has sparked tension in various parties. Surprisingly, this phenomenon actually hits the educated, those who understand religion sometimes behave fanatically and feel right with their own teachings.

An astonishing fact also came from the Ministry of Communication and Information which stated that until the end of July 2017, negative content based on SARA (Ethnicity, Religion, Race and Intergroups), including religious-based hate speech, reached the highest peak of 5,142 content (Pratama \& Sihombing, 2019). The terrible impact is that hate speech based on religion is very influential on the younger generation, especially school age. According to Maarif Institute researcher, that adolescents who are often exposed to negative content such as RHS tend to have intolerant attitudes towards people with different backgrounds from them (Yuliani, 2017).

An inevitable difference is difference. Difference is not used as a stumbling block, but as a stepping stone to improvement, togetherness and harmony. Even though they are different, at least various things can run harmoniously based on the principle of diversity. This attitude is actually maintained as a response to diversity (Tanuwibowo, 2010).

In line with the above, Al-Qardhawi (2019) also explained that differences of opinion, especially in the understanding of religion, especially in the furu'iyat area, are also important things, are a blessing, and as a space. Difference is also a divine gift that all religions should be grateful for and respond to well. The greater a community can accept differences, it is often positively correlated with the advancement of civilization and the higher the understanding of universal values. Considering Islam as a religion with these universal values (Shihab et al, 2019).

Seeing the reality that is increasingly worrying these days, it is important that religious moderation is presented in responding to the various differences that exist. One of the missions that needs to be encouraged is to present multicultural education as a knowledge base that equips religious practitioners, especially students as beginners. 
Madrasah (Islamic School) or Islamic boarding schools are easy targets for multicultural education that prioritizes Washatiyah Islam in the learning process. This is because the RHS conflicts that are rife are caused by conservative insights and thoughts in the religion (Saputra, et al, 2019).

Previous research by Najmina (2018) explained that multicultural education is also an important part of shaping the character of a nation that accepts diversity. In addition, research by Rosyada (2014) also explains that multicultural education can provide equal space to every student without having to differentiate from one another. In line with this, research by Adhani (2014) explains that multicultural education in schools must be optimized by providing knowledge and competencies that support the insights and actions of students in responding to diversity.

This study seeks to present a multicultural education concept that is different from the previous one. If the previous research initiated the concept of multicultural education in general, then this study will examine the concept of lita'arofu education contained in Surat Al-Hujurat verse 13 in addressing diversity. This of course will further illustrate Islam as a tolerant religion. This paper aimed to examine; (1) Blurred portrait of Religious Hate Speech (RHS) in Indonesia; (2) The urgency of multicultural education in addressing RHS; (3) Exploring the concept of lita'arofu as a model for multicultural education.

\section{METHOD}

The method used in writing this article is library research by collecting data from journal articles, books, and several electronic sources in the form of news and articles. Library research emphasizes the study of literature that is in accordance with the object of the research study (Zed, 2014). The approach used is a phenomenological approach. Phenomenology, is the real life experience as the basic data of reality. So that in phenomenological studies it is important not to fake phenomena, but rather can describe them as they appear. then look at the existing problems and look for solutions. The focus of the study in this paper is the elaboration of the concept of lita'arofu in the Koran as a model of multultural education to address the phenomenon of Religious Hate Speech. 


\section{RESULTS AND DISCUSSION}

\section{Blurred Portrait of Religious Hate Speech in Indonesia}

It is undeniable that the era of disruption contributed greatly to the dissemination of information. Every time people can access the media so quickly and update the latest developments. No wonder these conveniences support the spread of hate speech, especially on social media. The hate speech sometimes takes the name of religion as a mask. Yet if we look closely, any religion has never advocated hate speech.

For example, the hate speech uttered at the Ahmadiyah congregation by a leader of a religious mass organization in a tabligh akbar in Banjar, Tasikmalaya, West Java in 2008. Second, there are a number of social media accounts that spread the issue of radicalism and discredit Nahdhatul Ulama figures. Third, a lecture by one of the ustadz with the initials "KB" at the Saladin Mosque, Sidoarjo, East Java 2017 was deemed to contain hate speech because it was judgmental of people who were considered infidels without clarification. Fourth, as many as 336 provocative banners were removed by the Yogyakarta government because they contained a ban on carrying out funeral prayers for people who support leaders of different religions in mosques (Siregar \& Puri, 2017).

Recently, some residents in Nogosari Village, Jember, East Java have also received provocation regarding the funeral of the covid-19 body. Some villagers refused because the funeral was deemed not in accordance with Islamic law. This was triggered because there was an individual who said that the funeral for Covid-19 was not in accordance with Islamic law because it used a chest. Even though officers only carry out the funeral process in accordance with health protocols as understandable and even not disputed by religious leaders (Supriadi, 2020). This small phenomenon sometimes causes chaos in society just because there are differences that are understandable, but because of ego and narrow insights cause those who disagree to continue to reason.

In addition, on $5^{\text {th }}$ October 2020, social media was also shocked by hate speech made by a Facebook account named Allby Madura. The comment was considered to have an element of suspicion about the issue of the revival of the Indonesian Communist Party (PKI) and accused a number of kiai from the Karang Durin Islamic boarding school, Karang Penang, Sampang of being PKI (Syaifullah, 2020). Such accusations reflect a lack of insight and an attitude of fanaticism that is still strong. 
Chaotic speech of hatred against one group also occurred in 2019. Rinjani TV, which is a Wahabi-owned television station, is considered to have insulted the teachings of Nahdhatul Ulama. This is because Rinjani TV has repeatedly made posts insulting and demeaning the practices of Ahlussunnah Wal Jama'ah such as the Prophet's birthday, Tahlilan, and grave pilgrimages. In fact, they openly say that Islam has a Hindu flavor by thickening the $\mathrm{N}$ and $\mathrm{U}$ 's jokes and with a clear caption that makes fun of Aswaja's practice, namely the Tahlilan event for people who have died (Qolama.com).

Umar (2019) in his book highlights this phenomenon as school harassment. This form of RHS usually raises accusations of heresy, namely making changes to a practice and an understanding that is different from the mazhab adopted. In fact, preaching by vilifying others, let alone disbelieving it, is a way of preaching that is not familiar with the culture of Indonesian society. Because such preaching will only produce non-permanent Islam.

\section{The Urgency of Multicultural Education in Responding to RHS}

Multicultural education was born as a response to the heated differences. This is because multicultural education really honors humans because it sees all humans as equal, can work together and respect each other even though there are different cultures, races, ethnicities, religions, sexes and perspectives (Agustian, 2019). The implementation of multicultural education, especially related to religion, is very urgent as a vehicle for students to realize the diversity that exists (Sapsuha, 2013). Without mutual understanding, it is likely that conflicts will continue to occur, especially those related to religious-based hate speech.

Multicultural education becomes very important as a penetration of the continuing tensions of difference. Because with multicultural education that teaches mutual respect, these differences do not become a source of prolonged conflict and division. Based on the concept of Islam itself, multiculturalism becomes a divine rule that will not change. In fact, multiculturalism exists in the midst of an increasingly complex plurality of life (Setiawan, 2019).

Regarding the religious hate speech that is rife, there are several reasons that make multicultural education as a tension reducer are as follows. 


\section{First, Multicultural Education as an Insight Opener}

The RHS conflict that never goes out is caused, among others, by a narrow perspective on both religion and diversity. The concept of teaching that adheres to the allright principle is still being maintained, making the problem even higher. Multicultural education comes with all its principles that teach about the principles of mingling in diversity. Therefore, multicultural education has become the spearhead of the initial function of reducing tensions amid differences.

Sutiah (2015) in her book explains that through multicultural education, interreligious communities can find mutual understanding and gain knowledge as an insight enhancer so that they are not shortsighted in seeing those who are different. But what is more important is about the efforts of Muslims to build a balance and harmonization of religious relations that are more beautiful. For example, trying to accept different schools of thought and other differences related to worship or other urgent matters. Thus, multicultural education will open insights into these differences in a softer presentation and can be accepted by human common sense.

A study by Adibah (2014) has proven that multicultural education has succeeded in forming quality characters in responding to differences. This is manifested as a result of good insight into diversity. In the end, character building through multicultural education helps everyone to understand, understand, and respect those who come from different religions, cultures, ethnicities or races. Because actually those who have broad insight into the culture, religion, or teachings of others will increasingly understand and accept.

\section{Second, Multicultural Education as a Reducer of Fanaticism}

Indonesia is known as a country that has high diversity. Various ethnic groups blend into one united in the motto of Bhineka Tunggal Ika. The pluralistic condition of society in terms of culture, race, religion and social status tends to lead to potential division. In religious matters, for example, one of the most dominant occurrences lately is insulting other different teachings (Ambarudin, 2016).

Seeing this reality, multicultural education exists as a damper for excessive fanaticism which actually further stretches the differences. Multicultural education has the energy to unleash fanaticism by reconstructing empowerment and equality in diversity. 
The important message is about rebuilding an open mindset in releasing fanaticism that gave birth to conservative and even extreme views (Amirudin, 2018).

Through multicultural education, slowly extreme attitudes will soften by understanding the essence of difference which is really a reality. However, multicultural education does not necessarily explain the differences, but is able to trace the root of the problem on which the differences are formed. For example, in school matters, there are various arguments that underlie why there are differences. These differences can be rooted in the interpretation, methodology, and selection of the arguments used.

\section{Multicultural Education Model with the Concept of Litaa'rofu}

Qur'an as a book of guidance for the people certainly carries all the valuable lessons that can be used as guidelines in life. Each verse contains inspiration and ibrah which is drawn from the previous stories which can then be elaborated and realized today. In fact, each word contains incomparable wisdom and is then developed with various points of view to be implemented in life.

One of them is the verses of the Koran which are related to multi-language education. As stated in QS. Al-Hujurat verse 13 as follows.

"O people! Indeed, We have created you from a man and a woman, then We made you nations and tribes so that you would know each other. Verily, the noblest among you in the sight of Allah is the one who is most pious. Truly, Allah is AllKnowing, Most Meticulous. "(QS. Al-Hujurat: 13).

Al-Qurthubi (2009) explains the background of the derivation of this verse in connection with the Bilal bin Rabbah incident. Ibn Abbas said, "On the day of the conquest of the city of Makkah, Rasulullah Saw. ordered Bilal to go up to the Ka'bah to say the call to prayer. Because Sayyidina Bilal is known to have a beautiful voice. Atab bin Usaid bin Abi Al Ish said, 'Praise be to Allah who has taken my father so that he does not see this day.' Al Harith bin Hisham said, "Muhammad did not find mu'adzin apart from this black crow." Suhail bin Amr said, "If Allah wills something, He will change that thing." Abu Sufyan said, "I will not say anything, for fear that the Lord of heaven will tell him (to Muhammad)." Jibril then came to the Prophet and tell him what they said.

He called them and asked what they were saying, and they admitted it too. So Allah also revealed this verse to prohibit them from boasting about their lineage and wealth, and 
and forbidding them to despise the little people. Because the measure is piety. The meaning of God's word is that all humans come from Adam and Eve. In fact, the difference in glory is due to the piety possessed by each human being.

Katsir (2004) explains that through this verse Allah SWT spoke while informing mankind that He had created them from one soul, and from it He created their mate, Adam and Eve. Then furthermore He made them nations and tribes. In terms of glory, all human beings are considered the same, it's just that the difference is seen in terms of piety. Therefore, Allah forbids doing backbiting and berating each other, Allah reminds them that they are the same in terms of humanity.

Ath-Thabari (2009) interprets the word lita'arofu by knowing each other in the offspring (nasab). Because in fact humans were created with diversity by Allah SWT. As a sedative, Allah continues this verse by declaring that even though they are different, there is no difference between humans which is more noble except in submission. This shows that piety is a non-negotiable measure of glory. Its urgency is so exalted regardless of physicality, social status, and other things that most humans consider to be the best.

Meanwhile, Shihab (2012) explains that this verse is more specifically talking about the basic principles of human relationships. Because it no longer uses a calling that is addressed to believers, but rather to types of people. The word lita'arofu which is taken from the word arafa in this verse means knowing each other. This word editorial suggests about the reciprocal relationship that must be carried out by different parties so that each can understand each other. The stronger the recognition of one party to another, the more opportunities are opened for mutual benefit.

If look deeper into the verse, the word lita'arofu is described so briefly as a call to understand each other. Regarding the existing differences, lita'arofu is actually carried out by all parties, not just focusing on one party. This is because the editorial of the verse as interpreted by Shihab denotes an inseparable reciprocal relationship. So when there is chaotic polemic of differences in religious understanding, for example, the two conflicting parties should dig up information from each other so that they are not mistaken in generating perceptions.

Likewise, when examining the background of the derivation of this verse (Asbab al-Nuzul), when Bilal bin Rabbah is underestimated because of his social status, it signals 
the importance of being careful in justifying. This will have an impact on mistakes that can actually belittle or underestimate the status of others. Likewise with the problems that occur in religious groups that overthrow each other, they only look at one side which they consider inappropriate without paying attention to the other side. So the answer to this problem is the base of the last end of Surah Al-Hujurat verse 13 which implies the glory of a person or group based solely on Allah. For Allah knows best which of His servants are truly pious.

Drawing on the important meaning of lita'arofu as a model of multicultural education, at least there are some valuable messages that accompany this verse. Among the messages of multicultural education are as follows.

First, Turning from Qabilah to Ummah

The word qabaila as interpreted by Shihab (2012) in Surah Al-Hujurat: 13 is interpreted as a tribe whose scope is smaller than syu'ub (nation), namely the nation. This meaning is stretched more broadly into different groups. The differences in question can be varied, different ideologies, views, or religious understandings in responding to something in the khilafiyah (different views on issues of Islamic law). The sense of solidarity in these groups sometimes blurs unity. In fact, brotherhood is an important step in the framework of religion and ukhuwah Islamiyah (brotherhood) (Al-Adhim, 2016).

So appropriately, multicultural education material in schools is trying to direct students not only to be solid towards qabilah or their group but to mingle with other groups. The group in question is of course related to the understanding taught at school. For example, the base of the school is Aswaja understanding, so do not make students allergic to Muhammadiyah understanding. The wise attitude given is to reconcile the two through "recognition" of their differences and similarities. Recognizing is not enough, an educator must also be good at formulating logical reasons for these differences.

Thus the implementation of the concept of lita'arofu in slowly blending the qabilah into the ummah. Even in a previous study, it was stated that since early childhood education, multicultural life must be introduced. Because multiculturalism is actually about internalizing diversity in the environment so that children can grow well in diversity, understand differences, and be fair to each other (Puspita, 2013). When the understanding of this difference has been introduced since he was a child, the attitude will continue to stick until he is an adult which then becomes a principle of life. So that they 
no longer glorify their own teachings as the identity of their qabilah, but can understand each other in a more diverse order of the ummah (wider community).

\section{Second, Giving Choices is not Forced}

One of the biggest motives for religious hate speech is to force the same understanding on others. This certainly triggers conflict, because not everyone can accept the understanding that is believed. In fact, forcing understanding is not the right way to resolve differences, but what is more appropriate is agree in dis-agreement, which is to give others the freedom to agree or disagree with something (Tobroni, et al., 2018).

In this regard, multicultural education should be able to protect the differences that exist in the classroom. For example in the matter of Jurisprudence, when the teacher teaches students about the procedures for dawn prayer using qunut (a special prayer that is read in the dawn prayer), the teacher must also teach the procedures for the dawn prayer that does not use qunut. This becomes a broad scientific presentation so that they are not narrow-minded which then leads to the most true teaching claim.

This simple action in the classroom is one of the implementations of lita'arofu which seeks to introduce, understand, and be tolerant of the existing differences. Even if necessary, in certain learning the teacher must also introduce other religious rituals that aim to provide education so that students are not surprised when they see something different. But what needs to be emphasized is that the teacher's actions are only introductory, not to justify or imitate.

An earlier study by Rosyad (2019) explains that among the implementation of multicultural education in schools in shaping social attitudes are inclusive values (openness), prioritizing dialogue, human values, tolerance values, help, and the value of justice. This proves that multicultural education in schools actually collaborates the values of openness and social values that apply in society. Especially in responding to the influence of RHS which is increasingly prevalent today, students need to emphasize the attitude of openness, dialogue, and tolerance as part of the implementation of the concept of lita'arofu. 


\section{Third, Expanding Viewpoints}

The last part of developing the concept of lita'arofu is to broaden the perspective. This mission aims to view differences proportionally so that it is not easy to justify and respond to them appropriately. This multicultural education model actually seeks to make moderate Muslim students with broad insights. When responding to a wrong understanding, even though it does not immediately give judgment, it is still wise to be wise by exploring the motives of the problem and the background of a difference that appears.

The application of this model can be done in problem-based learning. For example, Jurisprudence learning which carries the theme of different schools of thought in society, the teacher can direct students to broaden their point of view in responding to these differences in understanding. A study by Rahmat (2019) explains that multicultural education is based on the pedagogy of human equality. This again reinforces the significance of the end of the letter Al-Hujurat: 13 which states that the level of humans is equal before Allah, only piety that distinguishes. Therefore something that looks wrong in the eyes of humans does not guarantee his humility before Allah Most High.

Likewise, the Koran recommends being wise in seeing differences, one of which is by avoiding hate speech. This is as stated in QS. Thaha verse 44 as follows.

"then speak both of you to him (Pharaoh) in gentle words, hopefully he is aware or afraid." (QS. Thaha: 44)

Katsir (2004) explains that this verse is related to Allah's command to Prophet Musa to speak to Fir'aun with a gentle tone. This was intended so that Fir'aun could melt with the message delivered by the Prophet Musa a.s. Because soft words can touch the soul, deeper and hit the mark. At first glance, this verse also describes the da'wah communication model used by the Prophet Musa, namely with a neat and wise approach.

The commandment in this verse actually offends the attitude of some groups who take differences in a violent way. In fact, if it is treated with calmness, it will leave more marks as was done by the Prophet Moses in the above verse. Thus, it is very important to broaden the perspective in terms of lita'arofu together with a communication model that is characterized by qaulan layyina (gentle words) in addressing the increasingly intense religious hate speech (RHS). 


\section{CONCLUSION}

The increasingly unsettling phenomenon of the Religious Hate Speech (RHS) encourages prevention and resolution efforts. This polemic emerged as a response to disharmony and misunderstanding of religious actors in responding to differences. So it is fitting that multicultural education is very important to be presented as a basis for a mentality to be moderate and reduce divisions. One of the concepts offered is the expression lita'arofu in Surat Al-Hujurat verse 13 which presents a model of multicultural education according to the Koran.

The concept of lita'arofu is interpreted as a reciprocal relationship between humans to get to know, understand, and be wise to one another. Among the development of a multicultural education model from the concept of lita'arofu is trying to change the direction from qabilah to the ummah, giving choices instead of imposing, and broadening the perspective of students. This concept should be implemented through learning in schools as an effort to implement a religious approach that is friendly to diversity. In addition, the application of this concept can be tested for its effectiveness and usefulness through subsequent research.

\section{REFERENCES}

Adhani, Y. (2014). Konsep Pendidikan Multikultural Sebagai Sarana Alternatif Pencegahan Konflik. Jurnal Sosio Didaktika, 1(1), 111-121. DOI: 10.15408/sd.v1i1.1211.

Adibah, I. Z. (2014). Pendidikan Multikultural Sebagai Wahana Pembentukan Karakter. Jurnal al-Madaniyah, 4(2), 175-190.

Agustian, M. (2019). Pendidikan Multikultural. Jakarta: Universitas Katolik Indonesia Atma Jaya.

Al-Adhim, A. (2016). Al-Quran Sebagai Sumber Hukum. Jakarta: PT Jepe Press Media Utama.

Al-Qardhawi, S. Y. (2019). Pengantar Politik Islam. Terj. Fuad Syaifudin Nur. Jakarta: Pustaka al-Kautsar.

Al-Qurthubi, S. I. (2009). Tafsir al-Qurthubi (17), terj. Akhmad Khatib. Jakarta: Pustaka Azzam. 
Ambarudin, R. I. (2016). Pendidikan Multikultural untuk Membangun Bangsa yang Nasionalis Religius. Jurnal Civics: Media Kajian Kewarganegaraan, 13(1), 28-45. DOI: https://doi.org/10.21831/civics.v13i1.11075.

Amirudin, N. (2018). Filsafat Pendidikan Islam Konteks Kekinian. Gresik: Caremedia Communication.

Ath-Thabari, A. J. M. B. J. (2009). Tafsir Ath-Thabari [23], diterjemahkan dari Jami" Al Bayan an Ta'wil Ayi Al Qur'an. Terj. Abdul Somad dan Abdurrahim Supandi. Jakarta: Pustaka Azzam.

Katsir, I. (2004). Lubabut Tafsir min Ibnil Katsir. Terj. M. Abdul Ghoffar \& Abu Ihsan alAtsari. Bogor: Pustaka Imam Syafi'i.

Najmina, N. (2018). Pendidikan Multikultural dalam Membentuk Karakter Bangsa Indonesia. Jurnal Pendidikan Ilmu-Ilmu Sosial, 10(1), 52-56. DOI: https://doi.org/10.24114/jupiis.v10i1.8389.

Pratama, E. D. \& Sihombing. A. (2019). Strategi Komunikasi Kominfo dalam Menghadapi Fenomena Penyebaran Ujaran Kebencian. Jurnal of Communication Studies, 5(1), 77-94. DOI: https://doi.org/10.37535/101005120186.

Puspita, W. A. (2013). Multikulturalisme dalam Pendidikan Anak Usia Dini. Visi: Jurnal Ilmiah Pendidik dan Tenaga Kependidikan Pendidikan Non-Formal, 8(2), 144-152. DOI: https://doi.org/10.21009/JIV.0802.8.

Qolama.com. (2019). Rinjani TV Dilaporkan ke Polisi Terkait Ujaran Kebencian.

Retrieved from https://qolama.com/rinjani-tv-dilaporkan-ke-polisi-terkaitujaran-kebencian/.

Rahmat. (2019). Pembelajaran Pendidikan Agama Islam Berwawasan Multikultural. Depok: Rajawali Press.

Rosyad, A. M. (2019). Implementasi Nilai-Nilai Multikulturalisme Melalui Pembelajaran Pendidikan Agama Islam. Risalah: Jurnal Pendidikan dan Studi Islam, 5(1), 1-18. DOI: https://doi.org/10.31943/jurnal_risalah.v5i1.90.

Rosyada, D. (2014). Pendidikan Multikultural di Indonesia Sebuah Pandangan Konseptual. Jurnal Sosio Didaktika, 1(1), 1-12. DOI: 10.15408/sd.v1i1.1200.

Sapsuha, M. T. (2013). Pendidikan Pascakonflik: Pendidikan Multikultural Berbasis Konseling Budaya Masyarakat Maluku Utara. Yogyakarta: LkiS Yogyakarta. 
Saputra, A, R. A. et al. (2019). Rumah Moderasi Beragama: Perspektif Lintas Keilmuan. Yogyakarta: Bening Pustaka.

Setiawan, E. (2019). Konsep Urgensi Pendidikan Multikultural dan Permasalahannya. Edudeena: Journal of Islamic Religious Education, 3(1), 25-35. DOI: https://doi.org/10.30762/ed.v3i1.1075.

Shihab, A, et al. (2019). Islam dan Kebhinekaan. Jakarta: Gramedia Pustaka Utama.

Shihab, M. Q. (2012). Tafsri Al-Misbah: Pesan, Kesan, dan Keserasian Al-Qur'an. Jakarta: Lentera Hati.

Siregar, M. R., \& Puri, V. Y. (2017). Relevansi Hate Speech atas Dasar Agama Melalui Internet dengan Cyber Terorism. Justisia Et Pax: Jurnal Hukum, 33(2), 103-124. DOI: https://doi.org/10.24002/jep.v33i2.1598.

Supriadi, B. (2020). Dinilai Tak Sesuai Syariat Islam Pemakaman Jenazah dengan Protokol Covid-19. Retrieved from https://regional.kompas.com/read/2020 /09/30/12350171/dinilai-tak-sesuai-syariat-islam-pemakaman-jenazah-denganprotokol-covid -19 ? page $=$ all .

Sutiah. (2015). Pendidikan Agama Islam di Desa Multikultural. Sidoarjo: Nizamia Learning Center.

Syaifullah. (2020). NU Jatim Kecam Ujaran Kebencian yang Sudutkan Kiai di Madura. Retrieved from https://jatim.nu.or.id/read/nu-jatim-kecam-ujaran-kebencianyang-sudutkan-kiai-di-madura.

Tanuwibowo, B. S. (2010). Bertambah Bijak Setiap Hari: $8 \times 3=23$ !. Jakarta: Gramedia Pustaka Utama.

Tobroni dkk. (2018). Memperbincangkan Pemikiran Pendidikan Islam: Dari Idealisme Substantif Hingga Konsep Aktual. Jakarta: Prenadamedia Group.

Umar, N. (2019). Jihad Melawan Religious Hate Speech. Jakarta: Elex Media Komputindo.

Yuliani, A. (2017). Ujaran Kebencian Picu Generasi Muda Jadi Intoleran dan Diskriminatif. Retrieved from https://kominfo.go.id/content/detail/11958/ ujaran-kebencian-picu-generasi-muda-jadi-intoleran-dan diskriminatif/0/ sorotan_media.

Zed, M. (2014). Metode Penelitian Kepustakaan. Jakarta: Yayasan Pustaka Obor Indonesia. 